\title{
The Role of Posters in Teacher Education Programs
}

\author{
By Justina O. Osa and Linda R. Musser \\ Pennsylvania State University
}

\begin{abstract}
Posters abound in education libraries as decorative objects yet few libraries realize the educational potential of the poster. Posters are colorful, attractive learning media which can enhance the learning environment. This paper describes the value of posters in the educational setting, offers suggestions on selecting posters for learning, and includes examples of various types of learning posters.
\end{abstract}

The competence of teachers is contingent to a large extent on the quality of the teacher education program that prepared them. The quality of the resources that support the teacher education program has been recognized as a crucial determinant of the quality of the knowledge and skills which the prospective teachers store in their repertoire. ${ }^{1}$ The National Council for the Accreditation of Teacher Education (NCATE), a body charged with ensuring the quality of teachers, suggests in an article "What to Look for in a Teacher Preparation Program" that one of the questions to ask in choosing a good teacher education program is "Does the institution have the resources necessary to support each of the programs it offers?"2 Furthermore, teachers are progressively being held accountable for student learning. Teachers have to devise ways and adopt teaching strategies that match the learning styles of all the students in a class. The acceptable practice is for teachers to carefully select instructional materials and activities that will stimulate all students' brains and facilitate effective learning for all students. When there is a fit across materials, teaching methods, teachers, and learners, learning for students is enhanced.

The role of the education library in this process is to provide materials that will enable teachers to prepare and present curricular topics in a variety of ways, making learning possible for all students, irrespective of their social, ethnic or cultural background, their ability, or learning style. Faculty in teacher education programs need to have access to such resources in order to demonstrate their use to teachers-intraining. These demonstrations typically occur in method courses during which faculty model methods of:
- integrating curriculum and instruction materials into teaching;

- creating learning environment that encourages active engagement in learning and self-motivation;

- creating learning opportunities that are adapted to the needs of diverse learners;

- using a variety of instructional strategies to encourage students' development of critical thinking, problem solving, and performance skills;

- devising different approaches to make the learning materials, especially complex materials, learnable to all students; and

- providing the opportunity for students to interact with information to be learned in diverse and different ways.

\section{Posters - An Often Neglected Type of In- structional Material}

According to Jensen, "our eyes register about 36,000 visual images per hour, while the retina alone supplies $40 \%$ of all nerve fibers that are connected to the brain; $90 \%$ of the brain's sensory input is from visual sources." ${ }^{13}$ Researchers report that the visual sense is responsible for $90 \%$ of brain stimulation ${ }^{4}$ and that vision and visual memory take up to two-thirds of the brain. ${ }^{5}$ Since the absorption of knowledge is the key to success in any educational system, it follows that education libraries should have collections rich in visual materials. A visit to any education library will confirm the fact that education librarians are aware of the need to build collections of visually stimulating resources. In addition to text books, curriculum guides, instructional materials, and juvenile books, one can find videos, manipulatives, kits, 
dioramas, multimedia, and e-media. A closer look at the collection, however, will likely show few posters. While posters abound in education libraries as decorative objects, few libraries realize the educational potential of the poster. Yet posters are colorful, attractive learning media which can enhance the learning environment.

While many of the newer text books are heavily illustrated, the text book cannot take the place of a learning poster. Most obviously, a student must first open the text book to view the illustration within whereas a poster is immediately in their view on the classroom wall. Additionally, unconscious learning can take place through exposure to the information on the poster. Finally, posters create a more stimulating and interesting environment for learning.

Why have they been overlooked? It is unlikely that it is due to their cost since posters are usually very inexpensive. The challenge of dealing with their size and shape is unlikely to be daunting to education librarians who routinely handle kits, puppets, and puzzles. Perhaps it is because posters effectively deliver very limited pieces of information. Posters as learning objects are not given adequate attention by the literature. Even ERIC, the premier database of educational resources, does not include many references to posters as separate learning objects. In any case, education libraries should include these objects as part of their collection of learning resources.

\section{Types of Learning Posters}

Learning posters can be grouped into four categories. Those that:

- illustrate a concept or thing

- demonstrate a process

- differentiate between similar things

- capture interest and stimulate emotion. Posters that illustrate a concept or thing have several uses. Their primary use is to simply provide an illustration of something. For example, a poster showing a volcano could be used in an earth science unit. A biology unit on biomes would benefit from pictures of deserts and rainforests. A secondary use of this type of poster is in foreign language instruction. A language unit aimed at teaching the names of parts of the body can be made more effective by using illustrations in conjunction with termi- nology. Posters are also an effective means of illustrating processes. Examples include posters showing the water cycle from rainfall to rivers to oceans to clouds, or posters showing how food gets from the producer to the table. The third type of poster is one that illustrates similar things, which allows users to see the differences between similar objects. An example of this type of poster would be one showing basketry from different cultures. The final category, posters designed to stimulate the imagination and interest in a topic, are the type most commonly found in libraries. The best example of this type is the READ series of posters published by the American Library Association. The primary purpose of these posters is to inspire rather than to educate. Additional examples of learning posters are provided in the appendix.

\section{Selecting Learning Posters}

Most posters are attractive but not all are effective teaching tools. A poster that promotes learning will have some or all of the following characteristics. The learning poster will:

- motive and inspire students to learn

- stimulate interest in the topic

- effectively illustrate a concept or skill

- give the teacher guidance on how to use the poster

- provide reproducibles for student use

- $\quad$ provide directions for hands-on activities

- provide suggestions for additional instructional activities.

In addition to these criteria, the poster itself should be well-designed, well-organized, legible, and attractive. The best learning posters present concepts succinctly, grabbing and retaining students' attention and interest.

\section{Conclusion}

Teacher education programs have the preparation of teachers as their overarching goal. The raison d'être of the education library is to meet the instructional and research needs of these teacher education programs. The success of teacher education programs can be linked to the adequacy of resources available in the education library. Education librarians have a rich tradition of collecting diverse types of materials that can be used to augment and stimulate learning at all levels. Posters are in- 
expensive and useful teaching tools and deserve a place in the collection as well as a place on the wall.

\section{APPENDIX - Examples of Learning Posters}

The String Instruments. St. Paul, MN: Trend Enterprises, 2001.

There is a colorful visual representation of the ten different string instruments. Each image is labeled. On the reverse side of the poster there are vital pieces of information on string instruments such as string instrument facts. To make learning information on the string instruments fun there is an Instrument Scramble which requires students to unscramble each of the string instrument names. An answer key is also provided. There are reproducible activity pages that teachers can use to help students learn important information on string instruments in general and on the ten string instruments shown on the poster.

Wind Instruments. St. Paul, MN: Trend Enterprises, 2001.

This poster has colorful pictures of fifteen wind instruments that are labeled. The instruments are put into two groups -- brass and woodwind. On the back of the poster is Wind Instrument Facts and facts on Woodwinds and on Brass. To make learning exciting for students there is also a Wind Instruments Crossword. The students are provided clues that assist them to complete the crossword. An answer key is provided. There are reproducible activity pages that teachers can use to help students learn important information on wind instruments in general and on the fifteen wind instruments shown on the poster.

Percussion Instruments. St. Paul, MN: Trend Enterprises, 2001.

Nineteen percussion instruments are displayed on the poster. On the reverse side are important features such as Percussion Instrument Facts, Percussion Instruments Word Search, an answer key, and reproducibles for instructional activities.

Weather. Grand Rapids, MI: Frank Schaffer Publications, 1989.

This interactive learning chart lets students move an arrow to desired weather photo such as windy, foggy, warm, cloudy, cold, rainy, snowy, sunny. On the reverse side of the poster is useful information including informa- tion on the weather and tips for activities. There are also reproducible activities.

What is a Bird? Grand Rapids, Ml: Frank Schaffer Pub., 1993.

This poster features a total of twenty-four birds. The front side of the poster presents nine birds in beautiful bight colors and a concise definition of birds and their basic biological information. The reverse side of the poster shows pictures of twenty-four birds. Each bird is put in a cell and there is a short write-up on each one of the birds. The information on the poster is reproducible for instructional use.

Life Cycle of a Frog. Grand Rapids, MI: Frank Schaffer Publications, 1992.

This poster presents in very simple colorful fashion the life cycle of a frog. The language is very elementary and understandable for young learners. On the back of the poster, there are different interesting and educational information on frogs titled Frog Talk, From Polliwog to Frog, Frogs and Toads, and Sleeping In. The exercise on Frog Talk allows students to have fun using Professor Croaker's code to fill in the missing words. Correct answers are provided. Information in the section titled Frogs and Toads is presented in overlapping circles that distinctly list how frogs and toads are similar and different. This presentation method makes it possible for students to complete the assignment on how frogs and toads are alike and different. This instructional presentation of concepts enhances the chances for all students to achieve in class. There are posters on other life cycles such as Life Cycle of the Butterfly, The Life Cycle of Cecropia, Life Cycle of Alaska Salmon, The Silkworm Life Cycle.

There are several posters that focus on different parts and systems of the human body. Some of them include:

1. The Nervous System, St. Paul, MN: Trend Enterprises, Inc., 2001.

2. The Digestive System. St. Paul, MN: Frank Schaffer Publications, 1992.

3. Reproductive, Endocrine, \& Excretory Systems. St. Paul, MN: Trend Enterprises, 2001.

These posters provide colorful, visual representations of the different systems. The different parts of each system is clearly labeled. On the reverse side of the posters are learning resource materials to further enhance the level of student comprehension of these systems. 
There are crossword exercises and special activities such as A-maze-ing Brains maze for the lesson on the nervous system, and Dig Those Bones for the lesson on the skeletal system.

How Plants Make Food. Grand Rapids, MI: Frank Schaffer Publications, 1994.

The poster gives a short introduction on how plants make food. The six steps of the process of photosynthesis are described in simple language. There are four reproducibles on the reverse side of the poster. They are: Nature's Food Factory; Plant Facts; Autumn Color Change; and Plants We Eat. The Brainwork is also provided to stimulate students' critical thinking.

Parts of A Letter ([S.I.] : Carson-Dellosa Publ., n.d.

This poster is a display of a business letter, a friendly letter, and an addressed envelop. Each component part of both the letter and envelop is labeled. There is even a U S Mail with the Pick up hours displayed. The mail man can be seen holding the letters he picked up with the ones he is about to distribute in his bag. On the reverse side of the poster there is a rich Letter Writing Resource Guide with some ideas for using the poster. Students have easy access to useful information on letter writing such as tips for writing both business and friendly letters, samples of letter, addressing an envelop correctly paying special attention to the three important areas - the delivery address, the return address and the stamp, and helpful facts about zip codes. Teachers are also given address of possible places to contact to get pen pals for their students.

The Eight Parts of Speech. Grand Rapids, Ml: Frank Schaffer Publications, 2000.

The eight parts of speech is the focus of this poster. A simple brief definition and examples of their usage in short sentences are given, and the parts of speech are highlighted in red to promote easy learning. Pictures illustrating the parts of speech are also provided. On the verso of the poster there are reinforcement exercises for students. For example the exercise on Common and Proper Nouns instructs the students to change the proper nouns to common nouns, and students are to circle adverbs and adjectives in the review exercises on adjectives and adverbs.
Using Sensory Words. Huntington Beach, CA: Creative Teaching Press, 1999.

Writing is a challenging activity for most students. This poster sparks students' power of imagination and encourages them to be creative, innovative and free to express themselves in unique ways that make sense to them. The poster gives examples of Touching Words, Seeing Words, Hearing Words, Smelling Words and Tasting Words. There are vibrant illustrations of the different groups of sensory words. On the reverse side of the poster there are four reproducibles for teachers to use to encourage students use sensory words effectively in their written assignments. Teachers are given ideas on how to use the reproducibles - Onomatopoetic Words, Cavorting Colors, to promote learning.

Statistics: Collecting and Representing Data. Grand Rapids, Ml: Frank Schaffer Publications, 1997.

This poster exposes students to the process involved in gathering and using data. In this "science court"' science is the law and scientific thinking rules." On the back side of the poster are sections on sample size, randomness, bias, and collection data. Students are told what to do to properly complete assignment in each of the sections. This is just one of the titles in the Science Court To Serve and Observe materials. Each poster focuses on one vital science concept, and students complete activities that make them put the science concept they are learning into practice. The mock court activities and scenes make learning science concepts pleasant and east to learn. Other similar titles include: Inertia, Water Cycle, Work, Gravity, Work, Gravity, and Sound.

The Food Pyramid. Grand Rapids, MI: Frank Schaffer Publications, 1993.

This poster is a colorful representation of the food pyramid. On the back side of the poster there is information on What is A Serving? There are reproducibles for the teachers to use in class. The Food Pyramid exercise instructs each student to make a balanced food plan for one day and to draw on the pyramid the foods the student selected. The exercise Food for Thought instructs the students to keep a record of everything they eat. The poster makes learn about the food pyramid a meaningful and useful for every day living. 
Newton's Apple Science Series. St. Paul, MN : Trend, 1996.

This set of posters teach students concepts by answering questions students often ask. These posters take advantage of the inquisitive tendencies in students to spark their problem solving skills, to promote discovery learning. For example, on the poster How does a Jumbo Jet Take Off? students are given information on forces. The four main forces -- lift, gravity, thrust and drag that act on a plane in flight are explained. On the reverse side of the poster there are instructional, hands-on, inquirybased, and reinforcement science activities for students. Posters in this group include How Does Television Work?, Why Does a Roller coaster Make Me Feel Sick?, and Why Do We Cry?

Social Studies posters series. Grand Rapids, MI: Frank Schaffer Publications, n. d.

There colorful, simple but very informative posters can enhance the teaching of social studies and make learning a pleasant and exciting experience for students. Such posters are The Declaration of Independence, The White House, The Pledge of Allegiance, and State Birds and Flowers. These posters provide vital information in very understandable language and form on each of the topics the posters focus on. For example, the poster on The Declaration of Independence lays out under the heading Events That led to the Declaration, and The Preamble. On the back of the poster are exciting instructional activities such as students' research on the Intolerable Act of 1774, a new Preamble to the Declaration of Independence, and newspaper assignment on the issue of all people being equal. The Debate Time instructs the students to work in groups of eight students.

\section{Foreign Language Posters}

These posters assist teachers in presenting concepts in languages other than English. In Spanish for example there are posters such as:

El Alfabeto. New York:_McGraw-Hill, n. d.

This poster helps teach the Spanish alphabet. There are pictures to make it easy for young learners to make the right sounds when reading the alphabets in Spanish.
Banderas de Europa,. Huddersfield, England: Schofield and Sim, n. d.

This poster helps teach students European flags. The Spanish name for each of the countries is given, and a colorful flag for each country is displayed. A map of Europe reinforces the location of each country.

Contrarios. Huddersfield, England: Schofield and Sim, n. d.

This poster teaches the concept of opposites. Pictures are provides to give the students visual meaning of the different examples of opposites given.

Dias de la Semana. Grand Rapids, Ml: Frank Schaffer Publications, 1997.

On this poster the seven days of the week are written in Spanish. The students can write on and wipe off this chart.

Las Estaciones. Huddersfield, England: Schofield and Sim, n. d.

This poster teaches the four major seasons in Spanish.

Los Colores,_Huddersfield, England: Schofield and Sim, n. d.

This poster teaches colors in Spanish.

Nuestro Cuerpo. Huddersfield, England: Schofield and Sim, n. d.

This poster teaches students the Spanish names for the different parts of the human bodies - both male and female.

Que Hora Es? Huddersfield, England: Schofield and Sim, n. d.

This poster teaches students how to tell the time in Spanish.

In German there are posters such as:

Zahlen 1-20. Huddersfield, England: Schofield and Sim, n. d.

This poster helps students learn to count 1-20 in German. Pictures are provided to help the children count numbers.

Unsere Korper. Huddersfield, England: Schofield and Sim, n. d.

This poster helps students learn the different parts of the human bodies, male and female, in German. 
Unser Sonnensystem. Huddersfield, England: Schofield and Sim, n. d.

This poster teaches the solar system in German.

Musikinstrumente. Huddersfield, England: Schofield and Simm, n. d.

This poster displays colorful visual representations of thirty musical instruments and their names in German.

Flaggen Europas. Huddersfield, England: Schofield and Sim, n. d.

This poster provides a colorful map of Europe and flags for each European country in German.

Die Uhrzeit. Huddersfield, England: Schofield and Sim, n. d.

This poster teaches students to tell the time in German.

\section{References}

${ }^{1}$ National Council for Accreditation of Teacher Education. (2001). What to Look for in a Teacher Preparation Program. Retrieved on August 10, 2004, http://www.ncate.org/ future/ lookfor.htm.

2

3 Jensen, E. (2000). Brain-Based Learning in Hardiman, M. H. (2003). Connecting Brain Research with Effective Teaching: the Brain-Targeted Teaching Model. Lanham, MD: Scarecrow Press.

${ }^{4}$ Visual Education. (2003). XY Multiply Poster: Educator's Guide. International Quality Education Environment. Retrieved August 10, 2004, http://www.iqee.com/XYPTv5.htm.

5 International Quality Visual Education. (2003). About Us. International Quality Education Environment. Retrieved August 10, 2004, http://www.iqee.com/about.html.

${ }^{6}$ Statistics Collecting and Representing Data. (1997). Grand Rapids, MI: Frank Schaffer Publications.

The next issue will feature ethical issues in educational libraries. Some of the important questions include:

- How do librarians teach students and faculty about ethnical practice relative to research processes?

- Why is plagiarism such a problem in higher education, and what can be done to address this issue?

- How does technology impact ethical issues in educational librarianship?

- How are the rights of patrons/users balanced with the needs of the collective?

- What unique ethical issues arise in online reference service, and how can they be addressed?

- Does the ethical code of the American Library Association fully cover educational library services?

The deadline for submissions to this issue is March 30, 2005. 